\title{
The Ethics of Border Guarding: A First Exploration and a Research Agenda for the Future
}

This is an Accepted Manuscript of an article published by Taylor \& Francis Group in Ethics and Education on 21 February 2018, available online:

https://www.tandfonline.com/doi/full/10.1080/17449642.2018.1443051

Peter Olsthoorn (corresponding author)

Netherlands Defence Academy

P.O. Box 90002 | 4800 PA | Breda

PHJ.Olsthoorn.01@mindef.nl

0031765273822

Dr Peter Olsthoorn is Associate Professor in Military Leadership and Ethics at the Netherlands Defence Academy. Besides leadership and ethics, he teaches on armed forces and society, war and media, and on ethics and fundamental rights in the European Joint Master's in Strategic Border Management. His research is mainly on topics such as military virtues, military medical ethics, drones and the ethics of border guarding. Among his publications are Honor in Political and Moral Philosophy (State University of New York Press 2015) and Military Ethics and Virtues: An Interdisciplinary Approach for the 21st Century (Routledge 2010).

Michelle Schut

Central Organization Integrity Defense (COID)

Utrecht, NL

M.Schut.03@mindef.nl

Dr. Michelle Schut is currently working as integrity advisor for the Ministry of Defense. Her dissertation Soldiers as Strangers: Morally and Culturally Critical Situations during Military Missions (2015) connects culture and morality in the context of intercultural interactions during present-day military operations. She conducted research in various countries, Sri Lanka, Dutch Antilles, and Afghanistan, and on different subjects, such as ethics, culture and psychology.

\footnotetext{
Abstract

Although the notion of universal human rights allows for the idea that states (and supranational organizations such as the European Union) can, or even should, control and impose restrictions on migration, both notions clearly do not sit well together. The ensuing tension manifests itself in our
} 
ambivalent attitude towards migration, but also affects the border guards who have to implement national and supranational policies on migration. Little has been written on the ethics that has to guide these border guards in their work. Juxtaposing the ethics of border guarding against the ethics of the somewhat related military profession, this article attempts to a) describe border guarding as a comparatively rule-guided profession; b) outline the aim and basis of the ethics education that prepares border guards for their work; and c) propose a research agenda for the future that should further our understanding of a) and b), but also help us improve the moral education of border guards.

\section{Key words}

Border guards, borders, human rights, migration, virtue ethics

\section{Introduction}

Working far from home in a culturally diverse multinational team, a European border guard observes how some of his team members mistreat migrants. This conflicts with his own values and standards. He confronts the border guards involved, and warns them that he will take further steps if things do not change for the good. To his relief, matters improve as a result of his intervention. ${ }^{1}$

At a time that many migrants risk their lives in search of safety and a better life, the moral aspects of the way we treat them attracts an increasing amount of interest. Nonetheless, although a lot has been written on the ethics of borders (with academics in general being more in favor of open borders than politicians and the population as a whole), the ethics of border guarding and border guards has received considerably less notice. Most articles on the moral aspects of borders do not go into the work of border guards at all (see for example Agnew, 2008; Haselsberger, 2014). Exceptions are a number of publications authored or commissioned by Frontex ${ }^{2}$ (since 2016 officially known as the European Border and Coast Guard Agency), the agency tasked with guarding the external land, sea and air borders of the European Union. These publications are, however, in general more written for practitioners than for an academic audience, and consist mostly of an enumeration of the rights and rules that border guards should uphold (see for instance Frontex, 2013). This lack of attention for the ethical aspects of the actual guarding of borders is a reason for concern, as the way border guards do their work affects countless people in a very direct manner.

\footnotetext{
${ }^{1}$ Border guard during a workshop on moral dilemmas in border guarding.

${ }^{2}$ An abbreviation of frontières extérieures (French for external borders).
} 
Topics that touch upon the ethical aspects of border guarding range from the very general what are human rights and what does the Western origin of most human rights mean for the wideness of their appeal? - to the more specific, such as profiling, the rights of vulnerable groups, the right to data protection and corruption. It is especially those more specific - but perhaps also more consequential - aspects of border guarding that up till now have not received the attention they deserve. Important questions are: which rights are at stake when migrants try to enter a country; what kind of dilemmas do border guards encounter; what does this mean for the perceived meaningfulness of work; what room for discretion (if any) is there; and does cooperating with colleagues from other cultures pose specific problems? More attention from ethicists and educationists for these moral aspects of the work of border guards, and for the way they are trained and educated, could lead to improved ethics education for border guards, and the development of best practices and work place mechanisms that would make unethical conduct less likely to occur.

But also the plights (and rights) of the border guards themselves, something often overlooked as a result of the understandable attention for the suffering of migrants fleeing war ridden societies, deserve more thought: border guards are, next to the immediate sufferers (the 'first victims'), potential second victims. Recent literature on military personnel and other professionals (such as health professionals) indicates that humanitarian catastrophes, and the dire situation at Europe's southern borders is a clear example of such a catastrophe, can harm the professionals involved (see for instance Seys et al., 2013). This is commonly called second victimhood. War veterans, for instance, can suffer from extensive feelings of guilt and shame, and it seems likely that the same could happen to today's border guards (see also Frontex, 2013, p. 49). They might suffer from PTSD, or, in case they were involved in, witness to, or unable to prevent unethical conduct, moral injury (Litz et al., 2009).

While sketching what border guarding ethics entails, we will regularly juxtapose it against the moral education most Western military personnel receive - not only because of the professional affiliation of the authors of this paper, but also because (semi-)military organizations such as the French Gendarmerie Nationale, the Spanish Guardia Civil and the Royal Netherlands Marechaussee are increasingly tasked with border guarding duties. In fact, some see a militarization of border guarding (Pevnick, 2011, p. 2; Jones and Johnson, 2016), while also immigration itself is now and then described using bellicose terms such as 'invasion' or 'threat' (see for instance Pevnick, 2011, p. 3). According to some critics, this militarization conveys the wrong message, as military personnel are typically used against people considered enemies - not a category migrants fall into.

At the same time, we see that military personnel are ever more used for tasks that resemble policing - the so-called constabularization of the military (Janowitz, 1960). This blurring of external and internal security (see also Jones and Johnson, 2016, p. 188) makes it likely that soldiers and 
border guards increasingly face somewhat similar ethical issues, as both groups of uniformed professionals have to deal with civilians in a vulnerable position. These civilians often come from a different cultural background, while also border guards and soldiers themselves more and more have to cooperate, far from home, with colleagues from different cultures. They do this, under the watchful eye of the media and public opinion, in circumstances that are in general stressful, and sometimes frustrating. These working circumstances not only increase the risk of unethical conduct towards outsiders; it also raises the chances of psychological harm for the border guards and soldiers themselves. Their moral education should prevent both from happening.

Yet, it is especially the moral education of border guards that is likely to benefit from a benchmark with the moral education in the military, not the other way around. Both as a topic of academic research, and as a professional ethic that offers guidance to those involved in border guarding, border guarding ethics is close to non-existent. Military ethics, on the other hand, is by now well-developed, both as a research subject and as a professional ethic. That is not to say that there are no other equally well-developed approaches that border guarding ethics might benefit from. Care ethics springs to mind: it emphasizes the moral significance of the inequality and dependency that characterize many social relations - such as for instance that between border guard and migrant - and the special duties that come with that (see for instance Slote 2007). ${ }^{3}$ Regrettably, care ethicists have hitherto not written on how an ethic of care would look like for border guards.

The next section elaborates on the moral aspects of border guarding, focusing especially on the predominance of rules and regulations, and the amount of discretion border guards have in their rather rule-dominated environment. The section after that shows how this emphasis on rules is largely consistent with the mainly functional aim and predominantly juridical basis of border guarding ethics education. Both sections are for the most part based on recent European experiences. On the basis of these two sections, the subsequent section outlines a first draft of a research agenda for the future. Implementing that agenda should give us insight in the moral complexities of border guarding and a better understanding of what border guards need most in their moral education. That section is followed by a conclusion that suggests some ways to improve that moral education.

\section{Moral complexities of border guarding: rules, ethics, and the role of professional autonomy} Soldiers see their work as a profession, 'a relatively "high status" occupation whose members apply abstract knowledge to solve problems in a particular field of endeavor' (Burk, 2002, p. 21). But as a hierarchical institution, soldiering differs from the traditional professions such as law and medicine in

\footnotetext{
${ }^{3}$ Levinasian ethics, stressing our ethical responsibilities in face-to-face encounters, is another interesting (and somewhat related) approach in his context.
} 
that the state or the people is the client, not the individual that needs assistance (Olsthoorn, 2010, p. 88). If soldiers would resemble other professionals on this point, their client would sooner be the local population in, for instance, Afghanistan or Iraq. What is more, soldiers are primarily trained and socialized within their institution, where doctors and lawyers receive most of their formal professional training before entering their job; their professional standards stem from universities and professional associations, not from their employing organization (Mintzberg, 1983, p. 192).

Border guards see themselves as professionals too (Bigo, 2014, p. 211), but here as well the client is the state (not the migrant seeking entrance), while professional standards originate within the border guarding institutions themselves. In some aspects border guarding is even somewhat less professionalized than the military. While many Western militaries have had their master curricula in place for quite some time now, the Joint Master in Strategic Border Management of Frontex had its first successful run in 2015-7. An important aim of this master is to contribute to a common 'border guarding culture' that is currently missing - Frontex does not have its 'own' border guards, but uses those EU member states make available. That border guards seem to enjoy international cooperation and joint training (Bigo, 2014, p. 214) is a reason for optimism on this point, while the fact that a lot of time, money and effort is spent on the education of border guards (and, especially, those leading them) testifies to the fact that the field tries to catch up.

However, providing border guards with an expert body of knowledge does not turn them into professionals. What distinguishes professionals from other employees who possess a fair amount of skill and education is that they are generally more loyal to their profession than to their employing organization (see also Mintzberg, 1983, p. 190). They therefore place their own judgment above that of their superiors, trusting that their education and professional experience make their call more informed than that of a manager who lacks that background. Being a professional hence comes with a considerable degree of professional autonomy (see also Cook, 2002, pp. 342-3). It seems, for instance, inherent to being a professional that it is not clear cut that the law should prevail if that law conflicts with professional ethical standards. If we look at the position of the American Medical Association, we read that

Ethical values and legal principles are usually closely related, but ethical responsibilities usually exceed legal duties. Conduct that is legally permissible may be ethically unacceptable. (...) In some cases, the law mandates conduct that is ethically unacceptable. When physicians believe a law violates ethical values or is unjust they should work to change in law. In exceptional circumstances of unjust laws, ethical responsibilities should supersede legal duties (American Medical Association 2016). 
How do the professional practices of border guarding and the military compare to each other and to other professions on this point? A recent handbook on military ethics, specifically meant for the ethics education of military personnel, makes a claim similar to that of the American Medical Association, but put more boldly:

(...) being a member of the military profession (...) means adhering to the ethical standards of that profession (...) rather than simply complying with the law. Thus, in any situation where law and ethics set different standards, a member of the military profession will follow the higher standard, inevitably the one required by ethics (...) (Coleman, 2013, p. 268).

Border guards do not seem to have that amount of discretion within their rule-dominated environment. The view put forward in a Frontex commissioned article on border guarding ethics is that

The ethics of border security should be contrasted with the law of border security, because ethics and law are distinct. Although laws are often consistent with ethical principles, there is no contradiction in the notion of an unjust or immoral law. Ethical standards can, for example, be used to criticize law (Centre for the Study of Global Ethics, 2010, p. 8).

Ethical standards can be used to criticize law, but it is implied here that they form no ground to go against the law; the authors clearly do not see room for border guards to deviate from what the law prescribes. Law, regulations, codes of conduct and human rights (or fundamental rights, which is the term the European Union uses) are leading.

The reliance on rights, rules and procedures shows also in the twenty-eight page code of conduct that Frontex expects all participants in Frontex operational activities to adhere to. This code is much longer, and much more detailed, than most codes of conduct in other professions. ${ }^{4}$ Although the foreword stresses that the code of conduct "is not a codification of legislation," and that complying with "behavioral standards which do not have the force of law" is important, its outlook is predominantly rule-based. The chapter that outlines the principles underlying the code emphasizes first of all that Frontex personnel should comply with all relevant laws, while the chapter that follows

\footnotetext{
${ }^{4}$ The Frontex Code of Conduct for all Persons Participating in Frontex Activities can be found at http://frontex.europa.eu/assets/Publications/General/Code of Conduct applicable to all persons participating in Frontex operational activities.pdf.
} 
specifies prohibited conducts. Frontex has an equally long and comprehensive code of conduct for something as specific as joint return operations. ${ }^{5}$

Now, on a positive note one could say that this emphasis on rules and procedures makes sense in many aspects, most of all because it provides people seeking entry or who are forced to return with some security regarding their treatment. With this emphasis on the rights of migrants, the Frontex code of conduct differs in an important way from many military codes, which are sometimes more about regulating the conduct of military personnel towards each other than about their conduct towards those they are to protect. Also, rules and codes ensure that border guards from different national, cultural and organizational backgrounds nonetheless work within a unified approach. Such a confidence in the salutary power of rules and codes has its drawbacks, though.

According to some authors the impact of codes of conduct is fairly limited (see for instance Verweij, Hofhuis and Soeters, 2007, p. 24, 34), while we already mentioned the inflexibility of rulebased approaches. Also, such approaches are more about inducing people to refrain from unethical behavior than about motivating them to behave humanely (Bandura, 2002), and could even lead to border guards committing so-called 'crimes of obedience' (Kelman and Hamilton, 1989). And although legal norms ideally codify that which is deemed just in larger society, in practice what the rules stipulate might differ from what most people's individual consciences would deem right and proper. Because the difficulty lies here in determining what the right thing to do actually is (following the law or obeying one's conscience), we call this a moral dilemma. Some choices border guards face are rather tests of integrity, however: it is clear what is the right thing to do, yet with considerable pressure (from peers, or the prospect of furthering one's own interest) to choose the wrong course of action (Coleman, 2009, pp. 105-6). Although there is a tendency to deem moral dilemmas more interesting or significant than tests of integrity, it is evident that border guards, in a position of power and dealing with vulnerable civilians, will encounter both kind of issues, and that their ethics education should prepare them for both. ${ }^{6}$

\section{Professional ethics education for border guards - aim and basis}

\footnotetext{
${ }^{5}$ The Code of Conduct for Joint Return Operations can be found at http://frontex.europa.eu/assets/Publications/General/Code of Conduct for Joint Return Operatio ns.pdf. There is also a fifty page guide for joint return operations, to be found at http://frontex.europa.eu/assets/Publications/General/Guide for Joint Return Operations by Air c oordinated by Frontex.pdf.

${ }^{6}$ But there are situations in which the distinction between ethical dilemmas and tests of integrity are blurred. For instance, one might think that loyalty to colleagues is nothing more than such a pressure. But if loyalty amounts to a value, and in most uniformed professions it is in fact a rather important one, then there is a dilemma again (see also Coleman, 2009, 112).
} 
An important first question regarding any professional ethics education concerns its aim: does it want to be functional, that is, aimed at making people better at their job, or aspirational, that is, designed to change people into more moral persons (Wolfendale, 2008). Underlying that question is the question whether there is a difference between (mainly functional) role morality and (more aspirational) general morality. Sometimes, this is clearly the case: a lawyer is expected to defend the guilty, spies must lie, and sometimes role morality will ask you to do more than is expected of ordinary civilians (Coleman, 2013). Although one could argue that also for military personnel role morality clearly differs from ordinary morality, we see that there is a tendency in many Western militaries toward a aspirational approach that aims at making soldiers better persons (see for instance Robinson, 2007; Van Baarle et al., 2015), mainly based on the view that a bad person is not likely to be a morally good soldier - although he or she could still be an effective one. For border guards, the answer to the question of the ultimate goal is less clear-cut, but the importance that border guarding organizations attach to rules and regulations suggests that a functional approach prevails.

The question about the aim of ethics education is separate from, but not unrelated to, the question what should be the basis of ethics education. Clearly, the aspirational approach focuses on character, while the functional approach is more about conduct. This corresponds loosely with two main strands in moral philosophy, virtue ethics and rule-based ethics. These two schools are also the two most likely candidates regarding the question what school in moral philosophy offers the best means to improve the chances of border guards behaving ethically - utilitarianism plays a role in the debate pro and contra open borders, but it is hard to see how it could form a basis for the ethics education for border guards. ${ }^{7}$

What speaks in favor of virtue ethics as a basis for ethics education is that it is concerned with character formation; it assumes that virtues and character are not inborn or God-given qualities, but can be acquired through training and practice. This means that virtue ethics is in keeping with the aspirational approach that many Western militaries take, and when it comes to preventing their personnel from misbehaving many militaries now see virtue ethics as an important complement to rules and codes imposed from above (Berghaus, 2016; Olsthoorn, 2010). ${ }^{8}$ That rules and codes are

\footnotetext{
${ }^{7}$ In theory, the utilitarian credo that all should count for the same would, if taken seriously and implemented with some objectivity, have the favorable outcome that more migrants would see their rights respected. In practice, many authors think utilitarianism is prone to be misapplied in a selfserving way, and hence consider it not suited as a basis for the ethics education for professionals. As one author writes, "utilitarianism would lend itself to abuse in precisely those kinds of situations in which ethical safeguards are most needed" (Snow 2009, 560). Utilitarianism is therefore perhaps more suited as a public philosophy than as a personal moral code (Goodin 1995, 11-12).

${ }^{8}$ This goes for both volunteer and for conscript forces (although the ethical frame work of for instance the Bundeswehr is perhaps more value based than virtue based).
} 
impotent when no one is around and that they lack the flexibility necessary in today's missions are seen as important drawbacks of rule-based approaches in a military context.

However, virtue ethics has its own drawbacks, the most important one being that it assumes a fairly straightforward relationship between character and conduct that, perhaps, does not actually exist. Modern research in social psychology suggests that the situation we find ourselves in determines our conduct to a far greater extent than we tend (or like) to think. In a way, this is the old insight that knowing the good and doing the good are not the same (see also Arjoon 2008, 235). ${ }^{9}$ This holds especially true in stressful circumstances. Doris and Murphy point out that in combat, situational forces are much stronger than those most of us will ever encounter, and they see sleep deprivation, military training and culture, (racial) ideology, and the role of the primary group as chief causes of unethical conduct (2007). Not surprisingly, there is an increasing amount of attention in military ethics education for the way situational factors can further unethical conduct; because most military ethicists see teaching virtues as the best way to underpin military ethics education, they are also keenly aware of its downsides (see for instance Mastroianni, 2011; Olsthoorn, 2017; Robinson, 2009). ${ }^{10}$

Although many of the just-mentioned situational factors might affect the functioning of border guards too, the scarce literature on border guarding ethics is largely silent on both virtues and the role of situational factors (see for instance Frontex 2013; Centre for the Study of Global Ethics 2010). We already noted that border guarding is a rule guided practice, and if we look at border guarding ethics education and training, as for instance laid down by Frontex in their fundamental rights Trainers' manual, we see that these take a rule-based approach too. That Trainers' manual, in its own words "primarily based on hard law ratified by governments" (Frontex 2013, p. 16), is the only document that can be found regarding the ethics education Frontex provides. Not unlike the Frontex code of conduct, it mainly catalogs the rights, regulations and case law border guards have to keep to. ${ }^{11}$

Border guards seem to have internalized this faith in what the rules stipulate. At a 2015 workshop for (managers of) border guards that was part of the above-mentioned Frontex Joint

\footnotetext{
${ }^{9}$ This insight is thus mainly about tests of integrity, as defined in the previous section: what is right and what is wrong is clear, but the situation induces one to choose the wrong course of action.

${ }^{10}$ Some suggest that the insight that the situation often determines our conduct undermines virtue ethics as a basis for moral education, but that seems an overstatement. Social psychology only shows that the influence of our natural dispositions is weak. That does not tell us a lot about the influence of virtues, which are the product of training and habituation (see also Sreenivasan, 2002; Croom 2014).

${ }^{11}$ The Fundamental rights training for border guards: Trainers' manual can be found at http://frontex.europa.eu/assets/Publications/Training/Fundamental Rights Training for Border Gu ardsl.pdf.
} 
Master in Strategic Border Management, many participants were of the opinion that, as rules and laws gave sufficient guidance, there were hardly any moral dilemmas in border guarding.

Consequently, few were able to come up with a dilemma they themselves had encountered during the exercise of their professional duties. Because the ethical dilemmas that they had faced were in their opinion modest or absent, the moral strain they had experienced was, in their own perception, limited too. Rules and regulations are there primarily to protect migrants, but by limiting the room for discretion they apparently also prevent border guards from incurring psychological damage, moral injury, etc., at least in the short term. ${ }^{12}$ Whether this reliance on rules will prevent border guards from psychical harm in the longer run we do not know. There is quite some literature describing the risks of PTSD and moral injury in several professions, regarding moral injury especially for the military (see for instance Litz et al., 2009), but not for border guarding. As these phenomena often manifest themselves after a longer period of time, it is perfectly imaginable that border guards who are now working at Europe's borders will suffer psychological damage in the years to come.

There is yet another side to this, however. In the previous section we already mentioned several drawbacks of an overreliance on rules and regulations. But perhaps the most important drawback is that it can impede the ability to see the moral aspect of what one is doing, while that ability is evidently an important prerequisite for moral deliberation and morally sound decision making. In the case of competing values, for instance between the safety of migrant minors (which might require the separation of minors) and the right to family life, there is not always a 'best' choice. So, often, one has to choose the 'lesser evil.' In such cases, it is especially important to be able to justify the decision taken and to explain how this decision serves the interests of all parties best. That requires that one is able to recognize that there is a moral dilemma, at the minimum. It is the ability to actually see moral challenges for what they are that can make people act ethically, even in spite of the situation (Arjoon, 2008, 225).

\section{A research agenda}

Based on the above, but also on the experiences of both authors in teaching in the module Fundamental Rights and Ethics in the Joint Master in Strategic Border Management of Frontex; an interview with a senior officer of the Royal Netherlands Marechaussee by both authors; interviews the second author held with border guards of the Royal Netherlands Marechaussee; and a field visit to a so called Hotspot of the European Union by the first author in April 2016, we think that a research agenda for the future should include the following.

\footnotetext{
${ }^{12}$ Research shows that military personnel who lack guidelines to deal with morally critical situations experience more moral dilemmas, increasing the likelihood of moral injury (Schut 2015). In a way, guidelines can turn moral dilemmas into tests of integrity.
} 


\section{Moral issues}

There are, first of all, numerous fairly specific moral issues and dilemmas to look into, for instance regarding profiling (when does profiling turn into discrimination); the separation of minors; the cultural sensitivities in the interaction with migrants; the complexities of working with border guards from other (European) countries; the moral and legal responsibilities (who bears responsibility/is liable when things go wrong: the national government, the European Union, Frontex, the border guards involved etc.); the safety of border guards themselves; the meaningfulness of their work; and the unavoidable tensions between organizational and political directives and one's own values and emotions. Some of these issues will bring personal morals into conflict with laws, rules and procedures, others will pose a test of integrity. How do border guards deal with such dilemmas and tests, how do these dilemmas and tests affect them, and are they sufficiently educated to deal with them?

\section{Moral education}

Regarding the moral education of border guards for the dilemmas and tests of integrity they are likely to face, practical questions are whether it is sufficiently elaborate, and where its contents could be improved, while more fundamental questions regard the aim (aspirational or functional) and basis (virtue ethics or rule-based ethics) of that moral education. And seeing the important differences between the virtue-based moral education of military personnel and rule-based education of border guards on the other, there is the additional question whether these differences will lead to tensions for military personnel tasked with guarding borders. A more general issue is whether the moral education and, consequently, the moral outlook of border guards is not too rule guided, and whether more room for professional autonomy, and more attention for character development and virtue ethics, would benefit the moral efficacy of border guards.

\section{Situational factors}

Notwithstanding the possible merits of a more virtue based moral education, the situation border guards find themselves in can limit the influence of a virtuous disposition, especially in situations where that virtuous disposition is needed the most. Factors that might affect the functioning of border guards include stress, sleep deprivation, and the national and organizational culture, but also the amount and kind of training and education that border guards have received. The social psychologist's advice to avoid morally challenging situations is clearly not very helpful for border guards, but with more knowledge about the influence of these factors border guarding agencies can do more to make working conditions less of a challenge for their personnel. 


\section{Corruption}

Corruption is an important issue, and one border guards say to struggle with a lot themselves. It seems to be more prevalent some countries than in others, and something that becomes more of an issue when a border guarding agency is growing rapidly (Heyman, 2017) - as is currently the case with Frontex, but also with the US Border Patrol (Heyman, 2017). This is not only (or perhaps not even mainly) a cultural phenomenon; it is also a result of the huge national differences in the remuneration of border guards that make this specific test of integrity harder for some than for others. A border guard who accepts a bribe to let someone through a checkpoint clearly fails this test - but so does a colleague who sees it happen and looks away. Reporting corruption is evidently the right thing to do. What complicates matters is that telling on a colleague can hamper one's own functioning if it leads to the deterioration of working relationships; in that aspect, a test of integrity can border on a moral dilemma for a border guard that is a witness to corruption.

\section{Cultural differences}

But even if corruption is as much a result of relative poverty as it is a cultural phenomenon, significant cultural differences between officials from different European regions is what underlies many of the issues border guards encounter. For instance, local authorities that border guards work with sometimes frame illegal migrants as criminals who have unlawfully entered their country (while others will have a more humanitarian outlook). This might lead to conduct towards migrants that is improper (say verbally aggressive) in the eyes of a border guard. Correcting the other in a very direct manner is not always a viable option, as that (as is the case with addressing corruption) could deteriorate work relations. Sometimes it is better to find another way of letting the other know that he or she should change his or her conduct and calm down ('Think of your heart!'). Cultural differences also influence the willingness (and the possibilities) to discuss stressful experiences with colleagues as a coping strategy, and the willingness to report misconduct of one's own colleagues. As to that last point: that border guards commonly work together with colleagues from different cultural and organizational backgrounds means that group loyalty probably plays less of a role in border guarding than in the military. Again, this is something that should be researched, especially as we know from the military that the strength of group loyalties can be inversely related to the respect shown to outsiders. ${ }^{13}$

\section{Moral responsibility}

\footnotetext{
${ }^{13}$ Only 47 per cent of the American soldiers and 38 per cent of the marines in Iraq held that noncombatants should be treated with dignity and respect (Mental Health Advisory Team, 2006).
} 
Finally, there are some more philosophical questions concerning the work border guards do, for instance about their moral responsibility if they get involved in morally ambiguous activities such as the deportation, or readmission, as the European Union euphemistically calls it, of migrants to countries that are said to be safe for them. ${ }^{14}$ Should border guards who oppose such a policy take a principled stance and ask not to be tasked with its implementation, ${ }^{15}$ or should they just fulfill their task as correctly and humanely as possible, with the idea that otherwise others will do the job, but perhaps less humanely? The primacy of rules also makes that they do not have to feel much responsibility for what happens just outside their domain, nor does it necessarily require them to reflect much on their role in the bigger scheme of things. As it stands, the emphasis on, and trust in, rules and regulations enables border guards to compartmentalize their experiences. For instance, in Greece the detention of migrants and camp management generally falls under the responsibility of the local authorities, but under the eyes of Frontex screeners and debriefers. The latter are aware of the fact that migrants are detained in unsafe and unhygienic circumstances, but many of them do not feel that that is necessarily their concern - and from a purely formal point of view it is in fact not.

\section{Conclusion - implications for the moral education of border guards}

In the ethics education for border guards potential moral issues are mainly seen through the lens of rules and regulations. And clearly, pointing out what is permitted and what is not, and what the consequences of transgressing these rules are, should have a role in any ethics education, if only because not adhering to them can be costly for perpetrator and victim alike. Undiluted adherence to one school in moral philosophy, whether it be duty-based ethics or virtue ethics, might be common in academia, yet one could argue that those involved in professional ethics education are almost duty-bound to take a more inclusive approach. For the ethics education of border guards, this would mean less emphasis on the rules, procedures, and codes, and more attention for character formation, but also for moral deliberation and dilemma training. Assuming that in border guarding virtue ethics could be a complement to the current rule-based approach, there are a few things to take into consideration.

\footnotetext{
${ }^{14}$ Regarding that moral responsibility, there are broader questions. For instance: borders are legal, but are they also ethical? And if not, what does that mean for border guarding? At first sight, not a lot. Clearly, the ethics of border guarding is very different from the ethics of borders; the distinction somewhat reminds of the distinction between jus ad bellum and jus in bello in military ethics. The traditional view is that a soldier can fight justly in an unjust war, and is not responsible for the unjustness of that war. Revisionists have challenged that distinction, arguing individual soldiers should not fight in wars that are unjust (McMahan 2004). So, arguing by analogue, if borders are unjust to some extent, does that mean that border guarding is sometimes unjust too?

${ }^{15}$ This somewhat resembles the debate about conscientious objection in military ethics (see for an overview Ellner, Robinson \& Whetham, 2014).
} 
We should first of all start thinking about which virtues border guards would actually need. Presumably, they are rather different from the inward looking virtues, such as loyalty, discipline and obedience, that most militaries espouse. Second, virtue ethics education often consists of teaching about virtues (and virtue ethics) rather than teaching virtues, which is something different altogether. Assuming that virtues can be taught, the question is how this can be done with border guards who receive their ethics training in a class room, at a moment in life when their character is more or less formed. What is more, it is even unsure whether elaborate ethics education for uniformed personnel has any tangible beneficial effects on conduct. ${ }^{16}$ We know little about best practices in military ethics, let alone in border guarding ethics. Last, there is the question to whom such a more virtue based ethics education should be directed. In the military most of the efforts in educating ethics are directed at (aspiring) officers, not at soldiers and non-commissioned officers. Although one could argue that it is primarily officers who should keep military personnel from crossing the thin line between legitimate and excessive force, with today's corporals and sergeants functioning with a considerable degree of autonomy, this argument seems no longer valid. Clearly, in teaching ethics to those involved in border guarding a similar bias should be avoided; it is especially the lower echelons who interact the most with migrants.

However, moral education should not only aim at furthering virtues, or respect for laws and regulations for that matter, but also at giving insight in the factors that make unethical conduct more likely to take place. A curriculum that does not address the shortcomings of a virtue based approach would be seriously flawed. Factors such as negative peer pressure, dehumanization, and fatigue do make unethical conduct more likely to occur. The insights social psychology offers should hence have a prominent place in the moral education of border guards.

The main purpose of any professional ethic, write Martin Cook and Henrik Syse in an editorial for the Journal of Military Ethics,

is to assist professionals to think through the moral challenges and dilemmas inherent in their professional activity and, by helping members of the profession better understand the ethical demands upon them, to enable and motivate them to act appropriately in the discharge of their professional obligations (2010).

\footnotetext{
${ }^{16}$ Martin Cook writes about the ethics education at military academies that there "is a fundamentally incoherent and confused welter of programs justified, if at all, by the belief that if ethics is important, throwing lots of resources at the subject from any number of angles and approaches must somehow be doing some good" $(2008,57)$.
} 
Such a professional ethic, both motivating and assisting professionals in the performance of their duties, is long overdue for border guards. This is all the more regrettable, since taking the ethical aspects of border guarding, and the framework of human rights it has to function within, seriously is vital to its legitimacy.

\section{References}

Agnew, J. 2008. "Borders on the mind: Re-framing border thinking." Ethics \& Global Politics, 1, 175191.

Arjoon, S. 2008. "Reconciling situational social psychology with virtue ethics." International Journal of Management Reviews, 10, 221-43.

American Medical Association 2016. "Preface and Preamble to the opinions of the AMA's Council on Ethical and Judicial Affairs." Retrieved from https://www.ama-assn.org/sites/default/files/mediabrowser/preface-and-preamble-to-opinions.pdf.

Baarle, E. van, Bosch, J., Widdershoven, G., Verweij , D.E.M., Molewijk, B. 2015. "Moral dilemmas in a military context. A case study of a train the trainer course on military ethics." Journal of Moral Education, 44, 457-478.

Bandura, A. 2002. "Selective moral disengagement in the exercise of moral agency." Journal of moral education, 31, 101-119.

Berghaus, P. T. 2016. "The problems of authority and the want of apprenticeship in soldiers' character development." Journal of Moral Education, 45, 324-337.

Bigo, D. 2014. "The (in) securitization practices of the three universes of EU border control: Military/Navy-border guards/police-database analysts." Security Dialogue, 45, 209-225.

Burk, J. 2002. "Expertise, jurisdiction, and legitimacy of the military profession." In The Future of the Army Profession, edited by D. M. Snider \& G. L. Watkins, 19-38. New York: McGraw-Hill Primus Custom Publishing.

Carrera, S., \& Den Hertog, L. 2016. A European border and coast guard: What's in a name? Brussels: Centre for European Policy Studies.

Centre for the Study of Global Ethics, University of Birmingham 2010). Ethics of border security, Frontex 64

Coleman, S. 2009. "The problems of duty and loyalty." Journal of Military Ethics, 8, 105-15.

Coleman, S. 2013. Military ethics. Oxford: Oxford University Press.

Cook, M. L. 2002. "Army professionalism: Service to what ends?" In The future of the army profession, edited by D. M. Snider \& G. L. Watkins, 337-54. New York: McGraw-Hill Primus Custom Publishing.

Cook, M. L. 2008. "Ethics education, ethics training, and character development: Who 'owns' ethics in the US Air Force Academy?" In Ethics Education in the Military, edited by P. Robinson, N. de Lee, and D. Carrick, 57-66. Aldershot: Ashgate.

Cook, M.L. \& Syse, H. 2010. "What should we mean by 'military ethics.'” Journal of Military Ethics, 9, 119-22. 
Croom, A. 2014. "Vindicating virtue: A critical analysis of the situationist challenge against aristotelian moral psychology." Integrative Psychological and Behavioral Science, 48, 18-47.

Ellner, A., Robinson, P., \& Whetham, D. , eds. 2014. When soldiers say no: Selective conscientious objection in the modern military. London: Routledge.

Frontex 2013. Fundamental rights training for border guards: Trainers' manual. Warsaw: Frontex.

Goodin, R. E. 1995. Utilitarianism as a public philosophy. Cambridge: Cambridge University Press.

Haselsberger, B. 2014. "Decoding borders: Appreciating border impacts on space and people." Planning Theory \& Practice, 15, 505-526.

Heyman, J. 2017. Why caution is needed before hiring additional border patrol agents and ICE officers. American Immigration Council.

Janowitz, M. 1960. The professional soldier. Glencoe, IL: Free Press.

Jones, R., \& Johnson, C. 2016. "Border militarisation and the re-articulation of sovereignty." Transactions of the Institute of British Geographers, 41, 187-200.

Kelman, H. C., \& Hamilton, V. L. 1989. Crimes of obedience: Toward a social psychology of authority and responsibility. New Haven: Yale University Press.

Litz, B. T., Stein, N., Delaney, E., Lebowitz, L., Nash, W. P., Silva, C., \& Maguen, S. 2009. "Moral injury and moral repair in war veterans: A preliminary model and intervention strategy." Clinical psychology review, 29, 695-706.

McMahan, J. 2004. "The ethics of killing in war." Ethics, 114, 693-733.

Mastroianni, G. R. 2011. "The person-situation debate: Implications for military leadership and civilian-military relations." Journal of Military Ethics, 10, 2-16.

Mental Health Advisory Team IV 2006. Operation Iraqi Freedom 05-07 final report. Available at http://www.griegermd.com/MHAT IV Consolidated Report.pdf

Mintzberg, H. 1983. Structure in fives. Englewood Cliffs: Prentice-Hall.

Olsthoorn, P. 2010. Military ethics and virtues: An interdisciplinary approach for the 21st Century. London: Routledge.

Olsthoorn, P. 2017. "Situations and dispositions: How to rescue the military virtues from social psychology." Journal of Military Ethics, 16.

Pevnick, R. 2011. Immigration and the Constraints of Justice. Cambridge: Cambridge University Press.

Robinson, P. 2007. "Ethics training and development in the military." Parameters, Spring, 22-36.

Robinson, P. 2009. "The fall of the warrior king: Situational ethics in Iraq." In Ethics education for irregular warfare, edited by D. Carrick, J. Connelly \& P. Robinson,75-86. Aldershot: Ashgate.

Schut, M. 2015. Soldiers as strangers: Morally and culturally critical situations during military missions. Doctoral dissertation, University of Nijmegen.

Seys, D., Wu, A.W., Gerven, E.V., Vleugels, A., Euwema, M., Panella, M., ... \& Vanhaecht, K. 2013. "Health care professionals as second victims after adverse events: a systematic review." Evaluation \& the health professions, 36, 135-162.

Snow, N. E. 2009 "How Ethical Theory Can Improve Practice: Lessons from Abu Ghraib." Ethical Theory \& Moral Practice, 12, 555-68.

Sreenivasan, G. 2002. "Errors about errors: Virtue theory and trait attribution." Mind, 111, 47-68.

Slote, M. 2007. The ethics of care and empathy. New York: Routledge. 
Verweij, D.E.M., Hofhuis, K., \& Soeters, J.M.M.L. 2007. "Moral Judgment within the armed forces." Journal of Military Ethics, 6, 19-40

Wolfendale, J. 2008. "What is the point of teaching ethics in the military?" In Ethics training and development in the military, edited by P. Robinson, N. de Lee \& D. Carrick, 161-174. Aldershot: Ashgate. 